\title{
International genetic evaluation for direct longevity in dairy bulls
}

\author{
F. Forabosco, ${ }^{1}$ J. H. Jakobsen, and W. F. Fikse \\ Interbull Centre, Department of Animal Breeding and Genetics, SLU, Uppsala, Sweden
}

\begin{abstract}
The aims of this study were to document, present, and discuss the procedure used to calculate the international estimated breeding value (EBV) for longevity for Brown Swiss, Guernsey, Holstein, Jersey, Red Dairy Cattle, and Simmental breeds. Data from 19 countries and 123,833 national sires' breeding value were used for this purpose. Trait definitions and national genetic evaluation procedures were first summarized; and this showed that differences among countries existed. International breeding values for direct longevity were calculated using a multi-trait across-country evaluation model. The data editing method was identical to the one used for the February 2007 routine international genetic evaluation. Estimated genetic correlations presented in this study were similar to those presented in the literature and, in general, differed from unity because of differences in trait definitions, culling reasons, data included, evaluation procedures, genotype-environment interactions, and weak genetic ties among countries. The average genetic correlations for Holstein ranged from 0.49 to 0.76. The genetic correlations for Brown Swiss and Guernsey ranged from 0.29 to 0.95 and from 0.30 to 0.89 , respectively. For Jersey and Red Dairy Cattle the genetic correlations ranged from 0.39 to 0.61 and from 0.30 to 0.96, respectively. For Simmental the genetic correlation was 0.59 . Different predictors were used at national levels to define combined longevity. These predictors were combined using economic and empirical weights. Three out of 15 countries published international EBV of direct longevity only and 12 out of 15 countries combined direct longevity with predictors (combined longevity). International breeding values for longevity were combined into the total merit index by most of the member organizations and made available to breeders across the world through magazines and Web sites. Even if some breeders are not familiar with longevity EBV, they will select for this trait automatically if they use the published total merit indexes.
\end{abstract}

Received March 31, 2008.

Accepted December 16, 2008.

${ }^{1}$ Corresponding author: Flavio.Forabosco@hgen.slu.se
Key words: longevity, international evaluation, multiple-trait across country evaluation, genetic correlation

\section{INTRODUCTION}

Longevity in dairy cattle is internationally recognized as an important trait for the dairy industry; and it can affect overall profitability considerably (van Arendonk, 1991). Today, nationally predicted sire breeding values for longevity are available in many countries around the world (Miglior et al., 2005). The internationalization of dairy cattle breeding requires that dairy bulls must be compared across countries, since a lack of information on foreign bulls compared with domestic bulls could lead to wrong selection decisions (Mark et al., 2002). National sire breeding values (BV) for longevity can be computed using, for example, linear, random regression, or survival models (Sölkner and Ducrocq, 1999; Veerkamp et al., 2001; Caraviello et al., 2004). Prediction of international sire breeding values for longevity using multiple-trait across country evaluation (MACE) was found to be feasible in several studies (Van der Linde and de Jong, 2002, 2003; Jakobsen et al., 2004).

Since 1994, the International Bull Evaluation Service (Interbull) has provided international genetic evaluations using MACE following the methodology introduced by Schaeffer (1994) and subsequently refined by, among others, Sigurdsson et al. (1996), Sullivan (1999), and Fikse and Banos (2001). Deregressed national sire breeding values are used as the dependent variable when computing the international sire breeding values. Differences in heritability, reliability, sire standard deviation, effective daughter contribution, and (co) variances among countries within breed are taken into account during the international evaluation (Fikse and Banos, 2001). An international genetic evaluation for direct longevity (DL) and combined longevity (CL) was investigated by Van der Linde and De Jong (2003) and exclusively for DL by Jakobsen et al. (2004). The first routine international evaluation for DL was carried out by Interbull in November 2004 using Holstein bull data from 13 countries. In August 2005 a routine international genetic evaluation for Ayrshire (known today as Red Dairy Cattle), Brown Swiss, Guernsey, Jersey, 
Table 1. Numbers of bulls per breed ${ }^{1}$ used for the February 2007 international routine evaluation for direct longevity by the International Bull Evaluation Service

\begin{tabular}{|c|c|c|c|c|c|c|}
\hline Country $^{2}$ & $\mathrm{RDC}$ & BSW & GUE & $\mathrm{HOL}$ & JER & SIM \\
\hline AUS & 378 & & 99 & 4,312 & 972 & \\
\hline BEL & & & & 524 & & \\
\hline CAN & 503 & 99 & 76 & 6,666 & 304 & \\
\hline DNK & 1,512 & & & 5,614 & 1,716 & \\
\hline $\mathrm{DNR}^{3}$ & & & & 185 & & \\
\hline FIN & 2,637 & & & 819 & & \\
\hline FRA & & & & 10,348 & & 2,661 \\
\hline $\mathrm{DEU}$ & 268 & & & 14,484 & & \\
\hline $\mathrm{DEA}^{4}$ & & 4,257 & & & & \\
\hline HUN & & & & 1,834 & & \\
\hline IRL & & & & 1,238 & & \\
\hline ISR & & & & 727 & & \\
\hline ITA & & & & 5,749 & & \\
\hline NLD & & 54 & & 8,786 & 45 & 60 \\
\hline NZL & 785 & 30 & 53 & 4,238 & 2,695 & \\
\hline ESP & & & & 1,339 & & \\
\hline SWE & 2,614 & & & 1,825 & & \\
\hline $\mathrm{CHE}$ & & 2,073 & & 839 & & \\
\hline GBR & 268 & & 177 & 4,310 & 261 & \\
\hline USA & 315 & 579 & 599 & 21,624 & 2,282 & \\
\hline Total & 9,280 & 7,092 & 1,004 & 95,461 & 8,275 & 2,721 \\
\hline
\end{tabular}

${ }^{1} \mathrm{RDC}=$ Red Dairy Cattle; BSW = Brown Swiss; GUE = Guernsey; HOL = Holstein; JER = Jersey; SIM = Simmental.

${ }^{2} \mathrm{AUS}=$ Australia; BEL = Belgium $; \mathrm{CAN}=$ Canada CHE $=$ Switzerland DEU = Germany; DNK = Denmark; $\mathrm{ESP}=$ Spain; FIN = Finland; FRA = France; GBR = the United Kingdom; HUN = Hungary; IRL = Ireland; $\mathrm{ISR}=$ Israel; ITA $=$ Italy; NZL $=$ New Zealand; NLD $=$ the Netherlands; SWE $=$ Sweden; USA $=$ the United States.

${ }^{3} \mathrm{DNR}=$ Denmark (Red Holstein).

${ }^{4} \mathrm{DEA}=$ German and Austrian data from a joint evaluation.

and Simmental bulls involving a total of 17 countries was held for the first time. Since the first routine evaluation for longevity, the international breeding values have been distributed among the member organizations and through them to the dairy breeding industries.

The objective of this study was to document the procedure used to calculate the international BV for longevity and discuss the main features of these evaluations for Brown Swiss, Guernsey, Holstein, Jersey, Red Dairy Cattle, and Simmental breeds. In addition, the use of the international BV among member organizations was investigated.

\section{MATERIALS AND METHODS}

\section{Survey of National Evaluation Procedures}

A survey of systems used for national genetic evaluations for longevity in the countries participating in international genetic evaluations for longevity was conducted. Countries were asked to provide information about trait definition, collection of data, statistical models, expression of breeding values, and other details about their national evaluation system by completing the Interbull's Form GE (Interbull, 2007a), which is routinely used to report details about national genetic evaluation systems. In addition, a questionnaire was sent to collect supplementary information about culling reasons, the use of indicator traits, and rules for publication of EBV for longevity.

\section{International Genetic Evaluation}

Data. National genetic evaluations for direct longevity from 19 countries [Australia (AUS), Austria (AUT), Belgium (BEL), Canada (CAN), Denmark (DNK), Finland (FIN), France (FRA), Germany (DEU), Hungary (HUN), Ireland (IRL), Israel (ISR), Italy (ITA), New Zealand (NZL), Spain (ESP), Sweden (SWE), Switzerland (CHE), the Netherlands (NLD), the United Kingdom (GBR), and the United States (USA)] and from one or more of the following breeds: Brown Swiss, Guernsey, Holstein, Jersey, Red Dairy Cattle, and Simmental, were used for the February 2007 routine international genetic evaluation (Table 1).

The data set used to calculate the international BV for direct longevity consisted of 123,833 national sires' BV after editing. The data editing method was identical to that applied for Interbull evaluations. The data set was composed as follows: 6 Brown Swiss populations (5.7\%), 5 Guernsey populations (0.8\%), 19 Holstein (18 Black and White and 1 Red Holstein) populations 
(77.1\%), 7 Jersey populations (6.7\%), 9 Red Dairy Cattle populations (7.5\%), and 2 Simmental (1 Simmental and 1 Montbeliard) populations (2.2\%).

Procedure. Two main steps were performed: step 1 was deregression and genetic correlation estimation, done during the test evaluation, and step 2 was deregression, sire variance estimation, and prediction of international BV done during the test and routine evaluation. In both steps, general requirements for the bulls were that they had to be AI bulls with daughters in at least 10 herds and that they had to be sampled through an official insemination scheme (Interbull, 2007b). In step 2, only bulls born since 1986 for Holstein and since 1981 for other breeds were considered. Bulls with second-country evaluations were included only when the predicted genetic merit met national standards for official publication in the country sending the data or where the predicted genetic merit was based on a minimum of 150,30 , or 80 daughters in 50 , 10, or 20 herds for Holstein, Guernsey, or other breeds respectively, and where the first-country evaluation was included in the data. Bulls with second-country evaluations based on more than $50 \%$ imported daughters or daughters from imported embryos were included only when the predicted genetic merit met national standards for official publication in the country sending the information and first-country evaluation was included in the data.

Step 1: Deregression and Genetic Correlations Among Countries. National breeding values for all AI bulls as defined above were deregressed within each country as described by Jairath et al. (1998) and were used as dependent variables in the MACE. Genetic correlations were estimated simultaneously for all countries and all breeds, except for Holstein, for which subsets of countries were considered (Klei and Weigel, 1998). Countries were grouped into sets of 3 , and per analysis correlations were estimated for countries present in 2 sets with the United States as the link provider. Genetic correlation estimates for all country pairs were obtained by considering all possible combinations of triplets of countries. Multiple-trait across-country evaluation software (Klei and Weigel, 1998; Klei, 1998) was used to obtain the genetic correlations. Starting correlations for the REML procedure were 0.85 and iterations were stopped when the relative change for all $\lambda_{\mathrm{ij}}=\mathrm{G}_{\mathrm{ij}} / \sqrt{ }\left(\mathrm{R}_{\mathrm{i}} \times \mathrm{R}_{\mathrm{j}}\right)$ was less than $10^{-6}$, where $\mathrm{G}_{\mathrm{ij}}$ was the sire covariance between country $i$ and $j$, and $R_{i}$ and $R_{j}$ the residual variance in country $i$ and $j$, respectively, or when the maximum change in correlation was less than $10^{-6}$ (Interbull, 2007c).

Genetic correlations used to predict international BV were obtained after postprocessing of the REML estimates. In the postprocessing, genetic correlations were required to be from 0.30 to 0.98 for all breeds and subsequently subject to a weighted bending procedure (Jorjani et al., 2003) so as to obtain a positive-definite genetic correlation matrix (Interbull, 2007c). The range (minimum to maximum correlation) was based on actual REML estimates from the first test evaluation for longevity for country pairs with a large (>50) number of common bulls.

Step 2: Deregression, Sire Variance Estimation, and Prediction of International $B V$. Deregression was calculated as above. Sire variances were estimated by REML using all bulls that met the conditions specified above. These values were subsequently used in MACE to predict international BV.

Multiple-trait across country evaluation was used to integrate deregressed national genetic evaluations from several countries within breed into international sire evaluations (Schaeffer, 1994; Mark et al., 2002). The effective daughter contribution was computed and reliabilities for international BV were approximated as suggested by Harris and Johnson (1998). Pedigree was traced back 2 generations and genetic groups were formed.

Genetic groups for phantom parents (of base animals and imported animals) were formed on the basis of country of origin (defined following country borders), birth year, population of origin, and selection path. Selection paths were sires, maternal grandsires, and maternal granddams, and distinct selection paths were maintained. Groups were required to include a minimum of 30 animals and the number of common bulls and common $3 / 4$ sib-family was determined to indicate the number of genetic ties among countries (Mark et al., 2002).

\section{RESULTS AND DISCUSSION}

\section{Trait Definition}

Trait definition for longevity included the number of days from first calving to culling (uncensored), or censoring (in the case of animals still alive at the time of data collection), or last milk record, or reappearance in a subsequent lactation (binary trait with missing observation), or months in milk.

The majority of countries (14 of 19) accounted for production in their national evaluation in some way. Adjustment of true longevity for production levels provides an approximation of functional longevity ( $\mathrm{Du}-$ crocq and Sölkner, 1998a,b). Functional longevity is the ability to delay involuntary culling because voluntary culling for low production can be an important reason for disposal.

More than half of the countries (10 of 19) used survival analysis (assuming sire or sire-maternal grandsire 
model) to analyze direct longevity (Table 2). The USA, NZL, and ISR used a single-trait animal model to analyze productive life (USA), herd life (NZL), and days from first calving to $8 \mathrm{yr}$ since first calving (ISR). On the other hand, CAN, GBR, IRL, and SWE used a multiple-trait animal model, while BEL used a random regression lactation survival animal model and AUS a repeatability animal model.

\section{Culling}

The term "cull" refers to all cows that leave the herd regardless of their destination or condition on departure. Culling has been referred to as either voluntary or involuntary. Voluntary culls are those where cows were sold or slaughtered because of low production; and involuntary culls are those removed from the herd because of mastitis, extreme lameness, poor reproduction, disease, or death (Fetrow and Norman, 2006).

Countries have different ways of defining when a cow is considered culled (Table 2). In most countries a cow is considered censored when she is no longer present in the milk recording system (15 of 18), no longer present in the herd ( 2 of 18 ) or after a fixed number of lactations (1 of 18). Table 7 has the principal reasons for culling among countries participating in international genetic evaluation for longevity. The most common reasons for culling were fertility or reproductive problems (10 of 10), low production (6 of 10), udder problems in general (4 of 10), mastitis, high SCS, or both (4 of 10), other diseases (1 of 10), milkability problems (1 of 10 ), metabolic problems (1 of 10), the advanced age of the cow (1 of 10), and conformation problems (1 of 10).

\section{Heritability}

The heritabilities used to predict breeding values for direct longevity were in the range of 0.016 (IRL) to 0.110 (ISR) for countries applying linear models and from 0.05 (HUN) to 0.181 (CHE Brown Swiss) for countries applying survival analysis (Table 2). Note that heritabilities from linear and survival models are not directly comparable.

\section{Genetic Ties}

Genetic ties quantified by the average number of common bulls and $3 / 4$ sib-families for Holstein bulls were generally strong among countries except ISR, FIN, and Danish Red Holsteins (Table 3). For colored breeds, links among countries were relatively weak, in general, compared with Holstein. The average number of common bulls and 3/4-sib families within breed was from 16 (NLD) to 127 (USA) for Jersey and 5 (DEU) to 54
(SWE) for Red Dairy Cattle. Links within Brown Swiss and Guernsey were from 10 (NZL) to 78 [German and Austrian data from a joint evaluation and USA] and from 18 (NZL) to 32 (USA), respectively. Simmental breeds were represented by only 2 countries, Montbeliard from France and Simmental from the Netherlands, and the number of common bulls and $3 / 4$-sib families was 48. Most bulls (i.e., young bulls) considered in international genetic evaluations have daughters in only one country.

The necessary across-country genetic correlations are often difficult to estimate because of weak genetic ties among dairy populations in different countries. Large amounts of data are available internationally; but national populations are often not well connected. Lack of sufficient genetic ties might also contribute to unreliable estimates of genetic correlation. Lack of good links among countries makes international evaluation a special challenge compared with national genetic evaluations (Mark et al., 2005).

\section{Genetic Correlations}

Across-country genetic correlations for direct longevity for all 6 breeds were strong on average (Tables 4, 5, and 6). For Brown Swiss, the genetic correlations among countries ranged from 0.29 (NZL-DEU) to 0.95 (NLD-USA); the highest average genetic correlations was CAN (0.76). A similar situation was found for Guernsey, with genetic correlations ranging from 0.30 (NZL-USA) to 0.89 (CAN-USA/GBR) and the highest average genetic correlations was also CAN (0.76). The average genetic correlation for Holstein ranged from 0.49 (ISR) to 0.76 (USA or CAN), and the highest genetic correlation was between CAN and USA (0.92). For Jersey, the average genetic correlation ranged from 0.39 (NZL) to 0.61 (USA), and the highest genetic correlation was between GBR and DNK (0.87). For Red Dairy Cattle, the highest average genetic correlation value and the highest genetic correlation were 0.71 (DNK) and 0.96 (CAN with USA), respectively. For Simmental breeds, the genetic correlation was 0.59. Estimated genetic correlations presented in this study were within the range of those presented in the literature (Van der Linde and de Jong, 2002, 2003).

In general, genetic correlations among countries could differ from unity because of genotype-environment interaction, differences in trait definitions and differences in national genetic evaluation procedures (Banos, 1998). Furthermore, weak genetic ties (Mark et al., 2005), misidentification (Banos et al., 2001) and choice of time period of data for correlation estimation (Tarres et al., 2007) may cause estimates of genetic correlations to differ from their true underlying values. 
Table 2. Information for 19 countries providing national genetic evaluation data for the International Bull Evaluation Service routine evaluation for direct longevity

\begin{tabular}{|c|c|c|c|c|c|c|}
\hline Country $^{1}$ & Breed $^{2}$ & $\begin{array}{l}\text { Data } \\
\text { since }^{3}\end{array}$ & Trait definition $^{3}$ & Culling information $^{3}$ & Model $^{3}$ & Heritability $^{3,4}$ \\
\hline & RDC, GUE, JER, HOL & 1975 & $\begin{array}{l}\text { Probability of surviving from one year } \\
\text { to the next. }\end{array}$ & $\begin{array}{l}\text { The presence/absence of the cows in the herd } 12 \text { mo } \\
\text { after the data anniversary }\end{array}$ & AM RP & 0.025 \\
\hline EL & HOL & 1973 & Survival over successive lactations & Cow present/absent in the milk recording system & AM RR & 0.106 \\
\hline & RDC, BSW, GUE, JER, HOL & $1980^{5}$ & Survival in the first three lactations & Cow present/absent in the milk recording system & AM MT & 0.0975 \\
\hline & HOL & $1980^{5}$ & Productive life span of the cow & Cow present/absent in the milk recording system & SM SA & 0.1385 \\
\hline $\mathrm{HE}$ & BSW & $1980^{5}$ & Productive life span of the cow & Cow present/absent in the milk recording system & SM SA & 0.181 \\
\hline $\mathrm{EU}$ & HOL, RDC & 1985 & Functional herd life & Cow present/absent in the milk recording system & SM SA & 0.166 \\
\hline $\mathrm{EA}^{6}$ & BSW & 1979 & Functional length of productive life & Cow present/absent in the milk recording system & SM SA & 0.120 \\
\hline JN & HOL & $1988^{7}$ & Productive life span of the cow & Cow present/absent in the milk recording system & SM SA & 0.050 \\
\hline NK & RDC, HOL, Red HOL, JER & 1984 & Productive life span of the cow & Cow present/absent in the milk recording system & SM SA & 0.117 \\
\hline 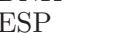 & HOL & $1986^{8}$ & Productive life span of the cow & Cow present/absent in the milk recording system & SM SA & 0.115 \\
\hline $\mathrm{N}$ & RDC, HOL & 1988 & Stayability from first calving & Not available & SM SA & 0.120 \\
\hline RA & HOL & 1988 & Productive life & Cow present/absent in the milk recording system & SM SA & 0.108 \\
\hline & MON & 1988 & Productive life & Cow present/absent in the milk recording system & SM SA & 0.130 \\
\hline LD & HOL, SIM, JER, BSW & $1988^{7}$ & Productive life span of the cow & Cow present/absent in the milk recording system & SM SA & 0.100 \\
\hline & RDC, BSW, JER, GUE, HOL & $1987^{5}$ & Herd life & Cow present/absent in the milk recording system & AM ST & 0.055 \\
\hline $\mathrm{BR}$ & HOL, RDC, GUE, JER & 1986 & Lifespan & Cow present/absent in the milk recording system & AM MT & 0.060 \\
\hline 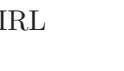 & $\mathrm{HOL}$ & 1980 & Survival to the next lactation & $\begin{array}{l}\text { Cows are considered culled when the interval between } \\
\text { the last test date and the last herd date known is }>140 \mathrm{~d}\end{array}$ & AM MT & 0.016 \\
\hline & HOL & $1985^{8}$ & Days from first calving to $2922 \mathrm{~d}$ & Exit dates are recorded in the milk recording system & AM ST & 0.110 \\
\hline & HOL & 1980 & Productive life span of the cow & Cow present/absent in the milk recording system & SM SA & 0.097 \\
\hline & $\mathrm{RDC}, \mathrm{HOL}$ & 1984 & Survival rate at second calving & Cow present/absent at the 2 nd calving & SM MT & 0.080 \\
\hline & RDC, BSW, JER, GUE, HOL & $1960^{5}$ & Productive life & $\begin{array}{l}\text { Cow present in the milking herd before removal } \\
\text { by voluntary culling, involuntary culling or death. }\end{array}$ & AM ST & 0.080 \\
\hline
\end{tabular}

${ }^{1}$ Countries participating in the international routine evaluation: AUS $=$ Australia; BEL = Belgium; CAN $=$ Canada; CHE $=$ Switzerland; DEU $=$ Germany; DNK $=$ Denmark; ESP $=$ Spain; FIN = Finland; FRA = France; GBR = the United Kingdom; HUN = Hungary; IRL = Ireland; ISR = Israel; ITA = Italy; NZL = New Zealand; NLD = the Netherlands; SWE = Sweden; USA = the United States.

${ }^{2}$ BSW $=$ Brown Swiss; GUE = Guernsey; HOL = Holstein; JER = Jersey; RDC $=$ Red Dairy Cattle; MON = Montbeliard

${ }^{3}$ Data included in national model, trait definition, culling information, national evaluation models $(\mathrm{AM}=$ animal model; SM $=$ sire model; ST $=$ single trait; MT $=$ multiple trait; $\mathrm{RP}=$ repeatability model; $\mathrm{RR}=$ random regression model; $\mathrm{SA}=$ survival analysis) and heritability for countries participating in the February 2007 international routine evaluation.

${ }^{4}$ Note that heritabilities from linear and survival models are not directly comparable.

${ }^{5}$ Year of first calving; lactation begins.

${ }^{6} \mathrm{DEA}=$ German and Austrian data from a joint evaluation.

${ }^{7}$ Cows in production.

${ }^{8}$ Calving since the year given. 
Table 3. Average number of common bulls per breed ${ }^{1}$

\begin{tabular}{|c|c|c|c|c|c|c|}
\hline Country $^{2}$ & HOL & $\mathrm{RDC}$ & BSW & JER & GUE & SIM \\
\hline AUS & 193 & 30 & & 112 & 27 & \\
\hline BEL & 124 & & & & & \\
\hline CAN & 270 & 35 & 27 & 69 & 21 & \\
\hline $\mathrm{CHE}$ & 134 & & 69 & & & \\
\hline $\mathrm{DEA}^{3}$ & & & 78 & & & \\
\hline DEU & 259 & 5 & & & & \\
\hline DNK & 126 & 9 & & 41 & & \\
\hline $\mathrm{DNR}^{4}$ & 5 & & & & & \\
\hline ESP & 206 & & & & & \\
\hline FIN & 31 & 41 & & & & \\
\hline FRA & 222 & & & & & \\
\hline $\mathrm{FRM}^{5}$ & & & & & & 48 \\
\hline GBR & 370 & 15 & 66 & & 21 & \\
\hline HUN & 186 & & & & & \\
\hline IRL & 174 & & & & & \\
\hline ISR & 28 & & & & & \\
\hline ITA & 246 & & & & & \\
\hline NLD & 271 & & 15 & 16 & & 48 \\
\hline NZL & 230 & 34 & 10 & 121 & 18 & \\
\hline SWE & 186 & 54 & & & & \\
\hline USA & 399 & 27 & 78 & 127 & 32 & \\
\hline
\end{tabular}

${ }^{1}$ BSW $=$ Brown Swiss; GUE $=$ Guernsey HOL $=$ Holstein; JER $=$ Jersey; RDC $=$ Red Dairy Cattle; SIM $=$ Simmental.

${ }^{2} \mathrm{AUS}=$ Australia; $\mathrm{AUT}=$ Austria $; \mathrm{BEL}=$ Belgium $; \mathrm{CAN}=$ Canada CHE $=$ Switzerland DEU $=$ Germany; DNK $=$ Denmark; ESP $=$ Spain $;$ FIN $=$ Finland; FRA = France GBR $=$ the United Kingdom; HUN = Hungary; IRL = Ireland; ISR = Israel; ITA = Italy; NZL = New Zealand; NLD = the Netherlands; SWE = Sweden; USA $=$ the United States.

${ }^{3} \mathrm{DEA}=$ German and Austrian data from a joint evaluation.

${ }^{4}$ DNR $=$ Denmark (Red Holstein).

${ }^{5} \mathrm{FRM}=$ France $($ Montbeliard).

Across-country genetic correlations are on average lower for longevity than they are for several of the other trait groups included in the Interbull evaluations. The first apparent difference in trait definition is the absence or presence of an adjustment for production. The presence or absence of such an adjustment potentially affects the definition/interpretation/meaning of longevity breeding values. For example, Van der Linde et al. (2007) compared true and production-adjusted longevity in The Netherlands, and reported a correlation between bull EBV of 0.80. Genetic correlations across countries tend to increase when trait definitions are more harmonized across countries (Emanuelson et al., 1999). Implementing an adjustment for production for all countries might affect genetic correlations across countries positively. For example, Van der Linde et al. (2007) reported that the genetic correlations with other countries were on average nearly 0.2 higher when using production-adjusted longevity instead of true longevity in the Interbull evaluation. The increase was larger for countries with production-adjusted longevity than for countries with true longevity.

There was much overlap among countries in the top 3 reasons for culling (Table 7), however, one can speculate

Table 4. Average genetic correlations per country $(\mu)$ and genetic correlations among countries ${ }^{1}$ (above diagonal) considered in the Interbull test evaluation for direct longevity for Brown Swiss and Guernsey breeds

\begin{tabular}{|c|c|c|c|c|c|c|c|c|c|c|c|c|}
\hline \multirow[b]{2}{*}{ Country } & \multicolumn{6}{|c|}{$\mathrm{BSW}^{2}$} & \multirow[b]{2}{*}{ Country } & \multicolumn{5}{|c|}{$\mathrm{GUE}^{2}$} \\
\hline & $\mathrm{CHE}$ & DEU & NLD & NZL & USA & $\mu$ & & $\mathrm{CAN}$ & NZL & USA & GBR & $\mu$ \\
\hline CHE & & 0.77 & 0.74 & 0.41 & 0.76 & 0.72 & CAN & & 0.56 & 0.89 & 0.89 & 0.76 \\
\hline DEU & & & 0.52 & 0.29 & 0.58 & 0.60 & NZL & & & 0.30 & 0.53 & 0.53 \\
\hline NLD & & & & 0.68 & 0.95 & 0.74 & USA & & & & 0.84 & 0.66 \\
\hline NZL & & & & & 0.50 & 0.44 & GBR & & & & & 0.72 \\
\hline
\end{tabular}

${ }^{1}$ AUS = Australia; CAN = Canada; CHE = Switzerland; DEU = Germany; GBR = the United Kingdom; NZL = New Zealand; NLD = the Netherlands; USA = the United States.

${ }^{2} \mathrm{BSW}=$ Brown Swiss; GUE = Guernsey. 
$\bar{\varnothing} \quad$ Table 5. Average genetic correlations per country $(\mu)$ and genetic correlations among countries ${ }^{1}$ (above diagonal) considered in the Interbull test evaluation for direct longevity for Holstein breed

\begin{tabular}{|c|c|c|c|c|c|c|c|c|c|c|c|c|c|c|c|c|c|c|c|}
\hline Country & BEL & CAN & CHE & DEU & DNK & $\mathrm{DNR}^{2}$ & ESP & FIN & FRA & GBR & IRL & ISR & ITA & NLD & NZL & SWE & USA & HUN & $\mu$ \\
\hline AUS & 0.73 & 0.61 & 0.53 & 0.56 & 0.66 & 0.56 & 0.34 & 0.57 & 0.69 & 0.67 & 0.61 & 0.53 & 0.36 & 0.64 & 0.70 & 0.64 & 0.68 & 0.32 & 0.58 \\
\hline BEL & & 0.78 & 0.72 & 0.83 & 0.75 & 0.74 & 0.53 & 0.55 & 0.67 & 0.86 & 0.81 & 0.55 & 0.54 & 0.76 & 0.68 & 0.75 & 0.82 & 0.47 & 0.70 \\
\hline CAN & & & 0.81 & 0.88 & 0.78 & 0.76 & 0.83 & 0.67 & 0.69 & 0.86 & 0.83 & 0.55 & 0.82 & 0.84 & 0.56 & 0.76 & 0.92 & 0.76 & 0.76 \\
\hline CHE & & & & 0.85 & 0.81 & 0.87 & 0.76 & 0.72 & 0.67 & 0.80 & 0.74 & 0.66 & 0.71 & 0.89 & 0.46 & 0.62 & 0.77 & 0.59 & 0.72 \\
\hline DEU & & & & & 0.82 & 0.84 & 0.78 & 0.70 & 0.65 & 0.86 & 0.88 & 0.43 & 0.76 & 0.82 & 0.54 & 0.74 & 0.86 & 0.66 & 0.75 \\
\hline DNK & & & & & & 0.81 & 0.70 & 0.85 & 0.76 & 0.78 & 0.67 & 0.53 & 0.68 & 0.89 & 0.51 & 0.74 & 0.86 & 0.57 & 0.73 \\
\hline DNR & & & & & & & 0.65 & 0.70 & 0.67 & 0.80 & 0.79 & 0.39 & 0.60 & 0.78 & 0.50 & 0.67 & 0.79 & 0.58 & 0.69 \\
\hline ESP & & & & & & & & 0.68 & 0.56 & 0.67 & 0.70 & 0.41 & 0.81 & 0.72 & 0.49 & 0.50 & 0.79 & 0.71 & 0.65 \\
\hline FIN & & & & & & & & & 0.76 & 0.60 & 0.67 & 0.57 & 0.53 & 0.76 & 0.47 & 0.64 & 0.70 & 0.42 & 0.64 \\
\hline FRA & & & & & & & & & & 0.64 & 0.62 & 0.62 & 0.64 & 0.81 & 0.41 & 0.64 & 0.70 & 0.55 & 0.65 \\
\hline GBR & & & & & & & & & & & 0.87 & 0.45 & 0.68 & 0.73 & 0.64 & 0.75 & 0.85 & 0.55 & 0.73 \\
\hline IRL & & & & & & & & & & & & 0.40 & 0.63 & 0.64 & 0.68 & 0.78 & 0.80 & 0.53 & 0.70 \\
\hline ISR & & & & & & & & & & & & & 0.42 & 0.74 & 0.33 & 0.44 & 0.48 & 0.37 & 0.49 \\
\hline ITA & & & & & & & & & & & & & & 0.72 & 0.34 & 0.53 & 0.74 & 0.84 & 0.63 \\
\hline NLD & & & & & & & & & & & & & & & 0.38 & 0.68 & 0.81 & 0.63 & 0.74 \\
\hline NZL & & & & & & & & & & & & & & & & 0.56 & 0.66 & 0.31 & 0.51 \\
\hline SWE & & & & & & & & & & & & & & & & & 0.76 & 0.45 & 0.65 \\
\hline USA & & & & & & & & & & & & & & & & & & 0.77 & 0.76 \\
\hline HUN & & & & & & & & & & & & & & & & & & & 0.56 \\
\hline
\end{tabular}

${ }^{1}$ AUS = Australia; $\mathrm{BEL}=$ Belgium; $\mathrm{CAN}=$ Canada $\mathrm{CHE}=$ Switzerland; DEU = Germany; DNK = Denmark; ESP = Spain; FIN = Finland; FRA = France; GBR = the United Kingdom; HUN = Hungary; IRL = Ireland; ISR = Israel; ITA = Italy; NZL = New Zealand; NLD = the Netherlands; SWE = Sweden; USA $=$ the United States.

${ }^{2}$ DNR $=$ Denmark (Red Holstein).

Table 6. Average genetic correlations per country $(\mu)$ and genetic correlations among countries ${ }^{1}$ (above diagonal) considered in the Interbull test evaluation for direct longevity for Jersey (JER) and Red Dairy Cattle (RDC) breeds

\begin{tabular}{|c|c|c|c|c|c|c|c|c|c|c|c|c|c|c|c|c|c|}
\hline \multirow[b]{2}{*}{ Country } & \multicolumn{7}{|c|}{ JER } & \multirow[b]{2}{*}{ Country } & \multicolumn{9}{|c|}{$\mathrm{RDC}$} \\
\hline & CAN & DNK & NLD & NZL & USA & GBR & $\mu$ & & CAN & DEU & DNK & FIN & NZL & SWE & USA & GBR & $\mu$ \\
\hline AUS & 0.38 & 0.28 & 0.31 & 0.54 & 0.71 & 0.31 & 0.42 & AUS & 0.43 & 0.83 & 0.63 & 0.53 & 0.54 & 0.74 & 0.38 & 0.30 & 0.55 \\
\hline CAN & & 0.34 & 0.45 & 0.30 & 0.80 & 0.67 & 0.49 & CAN & & 0.69 & 0.82 & 0.86 & 0.30 & 0.80 & 0.96 & 0.70 & 0.70 \\
\hline DNK & & & 0.68 & 0.30 & 0.37 & 0.87 & 0.47 & DEU & & & 0.90 & 0.66 & 0.30 & 0.84 & 0.67 & 0.43 & 0.67 \\
\hline NLD & & & & 0.31 & 0.54 & 0.61 & 0.48 & DNK & & & & 0.82 & 0.37 & 0.78 & 0.83 & 0.64 & 0.72 \\
\hline NZL & & & & & 0.57 & 0.30 & 0.39 & FIN & & & & & 0.40 & 0.60 & 0.83 & 0.85 & 0.69 \\
\hline USA & & & & & & 0.66 & 0.61 & NZL & & & & & & 0.49 & 0.30 & 0.30 & 0.38 \\
\hline GBR & & & & & & & 0.57 & SWE & & & & & & & 0.77 & 0.31 & 0.67 \\
\hline & & & & & & & & USA & & & & & & & & 0.61 & 0.67 \\
\hline & & & & & & & & GBR & & & & & & & & & 0.52 \\
\hline
\end{tabular}

${ }^{1}$ AUS = Australia; CAN = Canada; DEU = Germany; DNK = Denmark; FIN = Finland; GBR = the United Kingdom; NZL = New Zealand; NLD = the Netherlands; SWE = Sweden; USA = the United States. 
Table 7. Official longevity trait, indicator traits used for combined longevity, and main culling reasons in Interbull member organizations

\begin{tabular}{|c|c|c|c|c|c|c|}
\hline Country $^{1}$ & Breed $^{2}$ & Pub. $^{3}$ & $\begin{array}{l}\text { Official } \\
\text { trait }\end{array}$ & Traits combined & Method $^{4}$ & Culling reasons (up to 3 main reasons) \\
\hline AUS & BSW, GUE, HOL, JER, RDC & Yes & Comb. & Overall type, udder depth, pin set, and likability & SI & Low production, infertility, mastitis \\
\hline BEL & HOL & Yes & Comb. & Direct longevity, SCS and type traits & SI & Not available \\
\hline CAN & BSW, GUE, HOL, JER, RDC & Yes & Comb. & Mammary system, feet and legs, rump angle & $\mathrm{M}$ & Reproductive problems $29 \%$ \\
\hline $\mathrm{CHE}$ & $\mathrm{HOL}$ & Yes & Comb. & $\begin{array}{l}\text { Udder depth, SCC, days to first service, and feet } \\
\text { and legs composite }\end{array}$ & SI & Not available \\
\hline $\mathrm{DEA}^{5}$ & SIM & Yes & Comb. & $\begin{array}{l}\text { Conformation traits: udder, hocks, suspensory ligament, } \\
\text { udder depth, rear teat position, and feet and legs }\end{array}$ & SI & $\begin{array}{l}23.5 \% \text { fertility, } 17.9 \% \text { sold to another farm, } \\
11.5 \% \text { udder }\end{array}$ \\
\hline $\mathrm{DEA}^{5}$ & BSW & Yes & Comb. & $\begin{array}{l}\text { Conformation traits: form, udder, hocks, } \\
\text { suspensory ligament, udder depth, teat length }\end{array}$ & SI & $\begin{array}{l}24.4 \% \text { fertility, } 17.5 \% \text { sold to another farm, } \\
11.4 \% \text { udder }\end{array}$ \\
\hline DEU & HOL, JER, RDC & Yes & Comb. & $\begin{array}{l}\text { Direct long., feet and legs score, body depth, } \\
\text { udder depth, maternal stillbirth }\end{array}$ & SI & $\begin{array}{l}\text { Infertility } 23 \% \text {, udder diseases } 17 \% \text {, } \\
\text { feet and legs } 11 \%\end{array}$ \\
\hline DNK & HOL, JER, RDC & No & Direct & No & - & $\begin{array}{l}\text { Udder health, udder problems in general, } \\
\text { female fertility }\end{array}$ \\
\hline ESP & HOL & Yes & Comb. & SC count, udder depth, and feet and legs & SI & Not available \\
\hline FIN & HOL, RDC & No & Direct & No & - & $\begin{array}{l}\text { for RDC: Mastitis } 22.5 \% \text {, fertility } 21.5 \% \text {, } \\
\text { low production } 8.4 \%\end{array}$ \\
\hline FRA & BSW, HOL, SIM, MON & Yes & Comb. & See table notes ${ }^{6}$ & $-^{7}$ & Not available \\
\hline HUN & $\mathrm{HOL}$ & Yes & Comb. & $\begin{array}{l}\text { SCS, stature, rear udder height, udder depth, } \\
\text { and overall udder score }\end{array}$ & M & $\begin{array}{l}\text { Production } 22.24 \% \text {, fertility } 12.38 \% \text {, } \\
\text { udder health } 9.78 \%\end{array}$ \\
\hline IRL & HOL & No & Direct & No & - & Fertility $\sim 40 \%$ \\
\hline ITA & HOL & Yes & Comb. & Feet and legs composite & M & Reproductive problems $40 \%$ \\
\hline NLD & BSW, HOL, JER, SIM & Yes & Comb. & $\begin{array}{l}\text { SCS, interval calving insemination, body depth, } \\
\text { rump angle, udder depth, feet and legs }\end{array}$ & SI & Not available \\
\hline USA & BSW, GUE, HOL, JER, RDC & Yes & Comb. & $\begin{array}{l}\text { Direct longevity and correlated information } \\
\text { from all other traits in Net Merit. }\end{array}$ & SI & $\begin{array}{l}\text { Fertility } 20 \% \text {, mastitis or high SCS } 17 \% \text {, } \\
\text { low production } 13 \% \text {. }\end{array}$ \\
\hline
\end{tabular}

${ }^{1}$ AUS = Australia; BEL = Belgium; CAN = Canada CHE = Switzerland; DEU = Germany; DNK = Denmark; ESP = Spain; FIN = Finland; FRA = France; HUN = Hungary; $\mathrm{IRL}=$ Ireland; ITA = Italy; NLD = the Netherlands; USA $=$ the United States.

${ }^{2} \mathrm{BSW}=$ Brown Swiss; GUE $=$ Guernsey; HOL $=$ Holstein; JER $=$ Jersey; RDC $=$ Red Dairy Cattle; MON $=$ Montbeliard; $\mathrm{SIM}=$ Simmental.

${ }_{3}^{3}$ Combined longevity is/is not published.

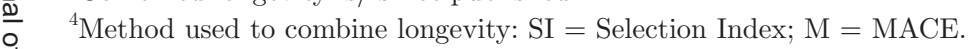

$\stackrel{5}{D} \mathrm{DEA}=$ German and Austrian data from a joint evaluation.

$\stackrel{\text { I. }}{\Sigma} \quad{ }^{6}$ For domestic bulls, France publishes combined longevity (Ducrocq et al., 2001) using the following as predictors (updated in June 2007): direct longevity, fertility (heifers and cows), () somatic cell count, milk production, milking speed, and conformation traits (for HOL, angularity, locomotion, udder depth, body depth, rump angle, fore udder). For international $\frac{\varrho}{\Phi}$. bulls, France published combined longevity only for HOL obtained by selection index method, using the following as predictors: direct longevity, somatic cell count, udder depth, body depth, and rump angle.

${ }^{7}$ Approximate multiple-trait BLUP is similar to MACE but takes into account residual correlations between traits measured on the same cow. 
whether the differences among countries are larger than this survey revealed. Another angle to view this from is in comparing the correlations between $\mathrm{BVs}$ for longevity and other functional traits; and these were found to differ considerably among countries (Powell and VanRaden, 2003). If there are different traits dominating culling reasons among countries (e.g., mastitis in one country and fertility in another), then the genetic correlation across countries for longevity is influenced by the genetic correlation among those traits. A complicating factor is that culling reasons may change over time (e.g., Ducrocq, 2004), and the choice of time period for data inclusion may be more important for international evaluations for longevity than for other traits.

\section{Combined Longevity}

The results from the questionnaire sent to member countries about combined longevity showed that countries had different policies on combining traits at a national level using different weights. National organizations used economic and empirical weights to combine different predictors in the total merit index (Table 7). These predictors included conformation traits, dairy production traits, SCS, calving traits, interval between calving and first insemination, days to first service, maternal stillbirth, fertility, and likeability in addition to direct longevity information, which is, for the most part, available only late in an animal's life. Most of the countries that published combined longevity at a national level (12 of 15) were using selection index ( 8 of 15), MACE (3 of 15), or an approximate multiple-trait BLUP animal model (1 of 15) methodology to combine the traits.

Research conducted by Van der Linde and de Jong (2002, 2003) suggested that it is better to use DL for international genetic evaluations than CL. Direct longevity is a more uniform trait than CL because CL is calculated by each member country in a different way. Furthermore, CL is a combination of various types of information that may be available at different points in the life of the cow and may not be identical to that which will be available later in the cows' lives, and this would bias the sires' BV over time. Nevertheless, CL is available earlier than DL and many countries use and publish it when computing a total merit index (Buenger et al., 2001; Miglior et al., 2005; Sewalem et al., 2005).

\section{Publication Rules}

International breeding values for direct longevity have been made available to member countries (since September 2007) 3 times per year (for the routine evaluation) and twice per year (for the test evaluation). Sires' breeding values are published nationally (Interbull, 2007d) according to the policies regarding national and international evaluations as described on the Interbull Web site (Interbull, 2007e). Member countries are responsible for distributing international BV for longevity among the breeders and the dairy breeding industry.

Most of the member countries published combined longevity nationally 3 times per year. The EBV for combined longevity was published at national level both in magazines and on Web sites (9 of 15 countries), only on Web sites ( 5 of 15 countries), and only in magazines ( 1 of 15 countries). The EBV for longevity are frequently combined at national level into a total merit index (VanRaden, 2004), and even if some breeders are not familiar with this trait they will select for it when they use the published indexes.

\section{CONCLUSIONS}

Genetic correlations for direct longevity for Holstein and colored breeds were medium to high and moderate to medium, respectively. The genetic correlations among countries differed from unity because of differences in trait definitions, weak genetic ties, and genotype-environment interactions. International EBV for direct longevity are calculated by Interbull and are made available to the member countries. The member countries can publish direct longevity or they can combine it with predictors (combined longevity). Most of the member countries include longevity in their total merit index. Through Web sites and magazines, sires' BV are circulated among the dairy breeders and the dairy breeding industries can benefit from this information. Longevity has become a very important trait internationally and the extra visibility provided through the launch of Interbull evaluations has led to many national improvements and helped breeders focus more attention on longevity.

\section{ACKNOWLEDGMENTS}

The authors offer their grateful thanks to the national dairy cattle genetic evaluation units for all the effort they put into providing the information necessary for this study.

\section{REFERENCES}

Banos, G. 1998. Review of international genetic evaluation procedures in dairy cattle. Anim. Breed. Abstr. 66:585-592.

Banos, G., G. R. Wiggans, and R. L. Powell. 2001. Impact of paternity errors in cow identification on genetic evaluations and international comparisons. J. Dairy Sci. 84:2523-2529. 
Buenger, A., V. Ducrocq, and H. H. Swalve. 2001. Analysis of survival in dairy cows with supplementary data on type scores and housing systems from a region of northwest Germany. J. Dairy Sci. 84:1531-1541.

Caraviello, D. Z., K. A. Weigel, and D. Gianola. 2004. Prediction of longevity breeding values for US Holstein sires using survival analysis methodology. J. Dairy Sci. 87:3518-3525.

Ducrocq, V. 2004. Illustration of a trend validation test for longevity evaluations. Interbull Bull. 32:151-156.

Ducrocq, V., D. Boichard, A. Barbat, and H. Larroque. 2001. Implementation of an approximate multitrait BLUP evaluation to combine production traits and functional traits into a total merit index. Page 2 in 52nd Annu. Mtg. EAAP, Budapest, Hungary.

Ducrocq, V., and J. Sölkner. 1998a. Implementation of a routine breeding value evaluation for longevity of dairy cows using survival analysis techniques. Proc. 6th World Congr. Genet. Appl. Livest. Prod. 23:359-362

Ducrocq, V., and J. Sölkner. 1998b. The survival kit-V3.0; A package for large analyses of survival data. Proc. 6th World Congr. Genet. Appl. Livest. Prod. 22:51-52.

Emanuelson, U., F. Fikse, and G. Banos. 1999. Impact of national evaluation models on international comparisons. Interbull Bull. 20:115-119.

Fetrow, J., K. V. Nordlund, and H. D. Norman. 2006. Invited review: Culling: Nomenclature, definitions, and recommendations. J. Dairy Sci. 89:1896-1905.

Fikse, W. F., and G. Banos. 2001. Weighting factors of sire daughter information in international genetic evaluations. J. Dairy Sci. 84:1759-1767.

Harris, B., and D. Johnson. 1998. Approximate reliability of genetic evaluations under an animal model. J. Dairy Sci. 81:2723-2728.

Interbull. 2007b. Code of practice. http://www-interbull.slu.se/ service_documentation/General/Code_of_practice/framesidacode.htm. Accessed Oct. 20, 2007.

Interbull. 2007a. Description of national genetic evaluation systems for dairy cattle traits as applied in different Interbull member countries. http://www-interbull.slu.se/national_ges_info2/ framesida-ges.htm Accessed Mar. 20, 2007.

Interbull. 2007c. Genetic correlations. http://www.interbull.org/ documents/genetic_correlation_estimation_procedure.pdf. Accessed Oct. 20, 2007.

Interbull. 2007d. Policies regarding national and Interbull evaluations. http://www-interbull.slu.se/eval/framesida-genev.htm Accessed Oct. 20, 2007.

Interbull. 2007e. Release dates of national and Interbull evaluation results. http://www.interbull.slu.se/eval/framesida-genev.htm Accessed Oct. 20, 2007.

Jairath, L., J. M. C. Dekkers, L. R. Schaeffer, Z. Liu, E. B. Burnside, and B. Kolstad. 1998. Genetic evaluation for herd life in Canada. J. Dairy Sci. 81:550-562.

Jakobsen, J. H., W. F. Fikse, and P. M. VanRaden. 2004. Feasibility of MACE for longevity for colored breeds. Interbull Bull. 32:59-64.
Jorjani, H., L. Klei, and U. Emanuelson. 2003. A simple method for weighted bending of genetic (co)variance matrices. J. Dairy Sci. 86:677-679.

Klei, B., and K. Weigel. 1998. A method to estimate correlations among countries using data on all bulls. Interbull Bull. 17:8-14.

Klei, L. 1998. Solving MACE equations. Interbull Bull. 17:3-7.

Mark, T., W. F. Fikse, U. Emanuelson, and J. Philipsson. 2002. International genetic evaluations of Holstein sires for milk somatic cell and clinical mastitis. J. Dairy Sci. 85:2384-2392.

Mark, T., P. Madsen, J. Jensen, and W. F. Fikse. 2005. Short communication: Difficulties in estimating across-country genetic correlations for weakly linked bull populations. J. Dairy Sci. 88:3303-3305.

Miglior, F., B. L. Muir, and B. J. Van Doormaal. 2005. Selection indices in Holstein cattle of various countries. J. Dairy Sci. 88:1255-1263.

Powell, R. L., and P. M. VanRaden. 2003. Correlation of longevity evaluation with other trait evaluations from 14 countries. Interbull Bull. 30:15-19.

Schaeffer, L. R. 1994. Multiple-country comparison of dairy sires. J. Dairy Sci. 77:2671-2678.

Sewalem, A., G. J. Kistemaker, and B. J. Van Doormaal. 2005. Relationship between type traits and longevity in Canadian Jerseys and Ayrshires using a Weibull proportional hazards model. J. Dairy Sci. 88:1552-1560.

Sigurdsson, A., G. Banos, and J. Philipsson. 1996. Estimation of genetic (co)variance components for international evaluation of dairy bulls. Acta Agric. Scand. Anim. Sci. 46:129-136

Sölkner, J., and V. Ducrocq. 1999. The survival kit: A tool for analysis of survival data. Interbull Bull. 21:73-81.

Sullivan, P. 1999. REML estimation of heterogeneous sire (co)variances for MACE. Interbull Bull. 22:146-148.

Tarres, J., Z. Liu, V. Ducrocq, F. Reinhardt, and R. Reents. 2007. Parameter estimation of type traits from France and Germany with a single-trait MACE model using DYD data. Interbull Bull. 37:98-101.

van Arendonk, J. A. M. 1991. Use of profit equations to determine relative economic value of dairy cattle herd life and production from field data. J. Dairy Sci. 74:1101-1107.

Van der Linde, C., and G. de Jong. 2002. Feasibility of MACE for longevity traits. Interbull Bull. 29:55-60.

Van der Linde, C., and G. de Jong. 2003. MACE for longevity traits. Interbull Bull. 30:3-9.

Van der Linde, C., A. G. F. Harbers, and G. de Jong. 2007. From functional longevity to productive longevity in the Netherlands. Interbull Bull. 37:203-207.

VanRaden, P. M. 2004. Invited Review: Selection on net merit to improve lifetime profit. J. Dairy Sci. 87:3125-3131.

Veerkamp, R. F., S. Brotherstone, B. Engel, and T. H. E. Meuwissen. 2001. Analysis of censored survival data using random regression models. Anim. Sci. 72:1-10. 